Article

\title{
Tourism Environmental Impacts Assessment to Guide Public Authorities towards Sustainable Choices for the Post-COVID Era
}

\author{
Selena Candia *(D) and Francesca Pirlone (D) \\ Department of Civil, Chemical and Environmental Engineering, University of Genoa, 16145 Genoa, Italy; \\ francesca.pirlone@unige.it \\ * Correspondence: selena.candia@edu.unige.it
}

check for updates

Citation: Candia, S.; Pirlone, F. Tourism Environmental Impacts Assessment to Guide Public Authorities towards Sustainable Choices for the Post-COVID Era. Sustainability 2022, 14, 18. https:// doi.org/10.3390/su14010018

Academic Editor: Oran Young

Received: 24 November 2021

Accepted: 18 December 2021

Published: 21 December 2021

Publisher's Note: MDPI stays neutral with regard to jurisdictional claims in published maps and institutional affiliations.

Copyright: (C) 2021 by the authors. Licensee MDPI, Basel, Switzerland. This article is an open access article distributed under the terms and conditions of the Creative Commons Attribution (CC BY) license (https:// creativecommons.org/licenses/by/ $4.0 /)$.

\begin{abstract}
The collapse of tourism caused by the COVID-19 pandemic is forcing many destinations to rethink their economic model, by focusing on sustainability and innovation. Advances in tourism impact assessment can not only improve tourism products and services, but also guide the sector towards responsible choices for the post-COVID era. The paper proposes a new way to assess tourism products using the Life Cycle Assessment-LCA methodology. Thanks to this method the authors quantify the environmental impacts of tourism choices and propose alternative green solutions. Innovation is therefore aimed at promoting a new awareness to support sustainable tourism after the COVID-19 pandemic. Once the impacts have been quantified, local governments can make decisions in their plans to promote the most sustainable solutions. The application of the methodology to a typical case study for the Mediterranean area-Cinque Terre National Park in the Liguria Region (Italy) - further helps administrations to transfer and replicate the authors' proposal. The proposed methodology is applied taking into account several priority issues for host territories such as the activities carried out by tourists, tourism mobility, and accommodation.
\end{abstract}

Keywords: sustainable tourism; life cycle assessment; post-COVID strategies; tourism planning

\section{Introduction: Tourism in the Era of COVID-19}

Until the beginning of 2020, tourism had experienced continued growth and it was considered as one of the fastest growing economic sectors in the world [1-4]. The tourism industry generated over USD 236 billion in 2019 [5]. It is one of the world's largest industries and, according to the UNWTO-United Nations World Tourism Organization-tourism, as economic sector, surpasses oil exports and food production in terms of business turnover [5]. In fact, tourism is perhaps, today, the most substantial and important industry [6-9], with the greatest impact on the environment but also on urban topography, and the most cashflow generating industry of the 21st century [10]. Tourism, as a very substantial industry, employs millions of people, moves billions of dollars, produces and induces technological innovation, and uses brute labor. It is globally considered as a competitive and dynamic sector and deemed a key driver for socio-economic progress [11-14]. In Italy, tourism, together with flow-on activities, generates about 13\% of GDP and jobs [15]. However, in addition to the direct impact, everything upstream and downstream must be considered, i.e., the so-called indirect impacts (Mason): how many buses would be manufactured without tourism? How many planes?

In 2020, the global economic situation following the COVID-19 pandemic has changed dramatically. Travel and tourism are among the most affected sectors [16-18] with a massive fall in international demand due to global travel restrictions including many boarders fully closed and the fear of infection. As 166 countries restrict entry into their national territories, global mobility have come to a near standstill leaving tourism destinations empty because their main resource, international tourists, were effectively absent [19]. UNWTO determined that international arrivals declined 74\% for the whole of 2020 [20,21]. This means that international tourism returned to levels 30 years ago. The World Travel and 
Tourism Council (WTTC) estimates that 75 million jobs are at risk globally with a potential Travel and Tourism GDP loss of up to $\$ 2.1$ trillion this year. Tourism workers consider 2020 as a missed season but 2021 is proving to be just as complicated. The beginning of the year 2021 has been worse for most destinations, with an average global decline of 88 per cent as compared to the pre-pandemic level; although, the northern summer and autumn may see a significant improvement for some destinations, in particular for domestic and regional travel [20]. The indirect effects of this decline are even more devastating, as labor and capital remain unused and the lack of demand for intermediate goods and services has a negative upstream effect into many sectors [20]. In 2020, tourists preferred unpopular and uncrowded destinations, often in the countryside, in order to be able to continue travelling while avoiding contagion [22-25]. It is important to highlight these new travel trends by analyzing the development prospects of the tourism sector that characterize the COVID era and will characterize the post-COVID era in the coming years. Resilience and adaptability are two key characteristics for a revival and restart of the hospitality and tourism sector [26-28].

A recovery of the economic, social, natural, and cultural heritage of destinations is necessary to relaunch tourism after COVID [29]. According to a survey carried out by the Centro Studi del Touring Club Italiano-within the TCI community made up of over 300 thousand people - in the summer of 2020, after an initial phase of great caution, $90 \%$ of Italians have regained a progressive confidence in going on holiday. However, $69 \%$ of those interviewed said that the coronavirus had certainly changed their way of travelling $[30,31]$. "Proximity tourism" was preferred $(72 \%)$ and more cautious behavior was adopted to reduce the risk of infection: fewer events and museums than last year $(67 \%)$, preference for little-known and presumably less crowded destinations (59\%), and less frequenting of bars and restaurants $(58 \%)$. The cautious approach to travel also affected the relational aspect: $42 \%$ in fact reduced their interpersonal relationships, avoiding making new acquaintances and establishing friendships. These analyses seem to show a new propensity towards less well-known destinations, where, however, the dependence of the local economy on the tourism sector is less strong. In the aftermath of the COVID 19 pandemic, the problems related to overtourism in some tourist destinations went from being purely problems related to the tourist sustainability of a location to health problems. The destinations that suffered most from overtourism are those that suffered most from the COVID-19 crisis [32-34]. According to Federalberghi-the trade association for accommodation facilities in Italy-Venice, a city that worked almost exclusively with foreign tourists, lost $90 \%$ of its presences. The Cinque Terre recorded a minus 75-80 per cent drop in presences in 2020; in Florence, an internal survey by the Florence Convention Bureau noted "a vertical collapse" of international arrivals in the city, with peaks of minus 70 per cent, a drop not offset by domestic tourism [35]. These data show that Italian destinations that most need to see tourists return are those that previously suffered from overtourism. In fact, in these destinations the local economy is highly dependent on tourism: in Venice 1 in 3 people work in the catering and accommodation sector; for the metropolitan area of Florence, the economic impact of tourism amounted to EUR 3,647,1 billion, of which about $70 \%$ in the city of Florence alone.

The collapse of tourism caused by the pandemic is forcing many destinations to rethink their economic model [36], by focusing on sustainability and innovation [37]. The data above mentioned also demonstrate a positive trend in demand for more responsible vacations. To jumpstart the industry in the post-COVID era, therefore, we must focus on this new environmental consciousness. To succeed in this, it is important that all the actors involved - tourists, residents, public administrations, and private businesses-act by pursuing common goals [38-40]. The sustainable destination is intended as a "host community" and the tourist or visitor is a kind of "temporary citizen" [41]. To support responsible tourism, it is also important to develop new tourism plans and solutions that take into account the tourism impacts [42-44]. Because, if on the one hand, tourism can be considered as an opportunity to improve the quality of life and income in host 
countries, on the other hand, it can contribute to the degradation of the landscape, the growth of inequality, cultural loss, immoderate consumption of resources (energy, water, land, etc.), and increase in waste production and transport demand [45,46]. Tourism is globally responsible for $8 \%$ of all carbon dioxide emissions, the most important greenhouse gas causing climate change [47]. However, in terms of radiative forcing, the direct measure for contribution to climate change, tourism even could have share of up to $12.5 \%$ [48,49]. Moreover, the greenhouse gas emissions of tourism are estimated to grow at a rather large rate, while globally emissions should be reduced with up to $80 \%$ by 2050 [50]. Finally, it has been shown that the eco-efficiency-the economic contribution per ton emissions-of tourism is rather low [51]. These data totally clash with the view, actually slightly common to many researchers in the past, according to which tourism is a low environmental impact industry [52-54]. Now, it is a shared concept that tourist activities are strongly related to the environment [55-57]. On the one hand, the natural environment itself may be considered as a major input resource to the processes of tourism industries, and, on the other hand, the development of tourism as a mass industry may severely increase its overall impact on the environment $[58,59]$. Despite an increasing number of publications in recent years highlighting the negative environmental and social impacts of tourism $[60,61]$, national and local governments continue to treat the tourism industry solely from an economic point of view. Existing tourism plans are mostly territorial marketing tools and not tourism management (spatial, resource requirements, flows, etc.) [62].

Sustainable tourism is globally recognized as the only solution against the negative impact of mass tourism $[63,64]$. The UNWTO defines sustainable tourism as "a form of tourism that meets the needs of travelers and host regions while protecting and improving opportunities for the future". The Italian Association of Responsible Tourism (AITR) states that "sustainable tourism is implemented according to principles of social and economic justice in full respect of the environment and cultures. It recognizes the centrality of the host community and its right to be a protagonist in the sustainable and socially responsible tourism development of its territory. It works by fostering the positive interaction between the tourism industry, local communities, and travelers". The development of sustainable tourism takes into consideration several issues to work on: biodiversity and the preservation of natural heritage, the protection of local communities and the enhancement of cultures and traditions and the creation of sustainable economic actions in the field of tourism that aim to alleviate poverty. Promoting sustainable tourism means rethinking traditional tourism by considering the three aspects of sustainability, environmental, social, and economic, in an integrated and comprehensive way. There are three main actions that this new form of travel must pursue: welcoming, involving, and satisfying guests; protecting and improving the environment; and developing the local economy. Sustainable tourism, unlike mass tourism, listens to the needs of the individual traveler $[65,66]$ by offering him a unique experience, while minimizing the negative effects on the environment, the economy, and the host society. It aims to create new jobs and improve the local economy by enhancing traditions and typical products.

If the pre-COVID tourism trend were to be reconfirmed in the coming years (WTO forecasts that we will reach the same levels as in 2019 by 2023) [20], the global situation would become even more unsustainable with emissions related to tourism transport tripling in 30 years. To be able to talk about sustainability in tourism, it is necessary, to analyze its impacts on the natural and socio-cultural environment of a destination and then adopt the necessary measures to reduce/eliminate the negative effects and enhance the positive ones through the promotion of sustainable solutions. However, it is not easy to measure the impacts of tourism $[67,68]$, so the paper proposes a methodology that can help local governments in choosing the greenest tourism solutions to promote in their territories and tourism plans. In particular, the paper intends to use the LCA methodology, normally applied to assess the sustainability of industrial products, to investigate tourism products and assess the greenest choices in terms of means of transport, accommodation facilities, 
and tourism activities/experiences. The aim is to give local authorities a scientific tool to understand and compare the environmental impacts of different travel solutions.

\section{Materials and Methods: LCA to Get Tourism Product More Sustainable}

The paper proposes a new methodology to promote sustainable tourism. Advances in tourism impact assessment can not only improve tourism products and services, but also guide the sector towards responsible choices for the post-COVID era. The paper proposes a new way to evaluate tourism products using the Life Cycle Assessment-LCA methodology. Thanks to this method the authors quantify the impacts of tourism choices and identify the greenest solutions that local administrations should encourage for the tourist development of their territory. The aim is to increase the direct involvement of people and local communities in an intelligent and balanced management of resources. LCA is a quantitative approach that takes into account the entire life cycle of a product (use of raw materials, pre-production processes, production, consumption, and end of life/recycling) to assess its overall sustainability [69-73]. Although LCA was initially conceived for the analysis of products, it can easily be used to evaluate services [74-77] and therefore can be applied to tourism. Being an all-inclusive methodology, it can identify potential shifts in economic, environmental, and social burdens from one life cycle stage to another, from a certain geographic area to another, and from one sustainability issue to another $[78,79]$.

LCA is also considered an environmental tool to support the implementation of the European Sustainable Consumption and Production Action Plan (SCP) in the travel and tourism sector. Accommodations, destination activities, and transportation are the factors [80] that generate the majority of GHG emissions from tourism [81]. Overall, the tourism industry is responsible for approximately $8 \%$ of the global carbon footprint of which approximately $60 \%$ is due to tourism transportation [82,83]. As the importance of tourism to the world economy continues to increase, the environmental aspects and impacts generated by its activities should be carefully considered from a Life Cycle Thinking (LCT) perspective.

To analyze tourism according to the logic of LCA, it is necessary to identify what is meant by a tourism product. It is not a simple product, but a wide range of goods and services that interact with each other to collectively create a tourism experience with tangible aspects (e.g., hotel, restaurant, and airline) and intangible aspects (e.g., sunset, landscape, and atmosphere) [84]. Middleton (1989) notes that the term "tourism product" is used at two different levels: the "specific" level (i.e., a unique product offered by a single company, such as a sightseeing tour or airline seat) and the "total" level (i.e., a tourist's complete experience from the time they decide to leave home to the time they return) $[85,86]$. This paper considers the tourism product at the "total" level by assessing the environmental impacts of a vacation. The tourism product analyzed includes several possible alternatives depending on the means of transport used to reach the chosen destination, the type of accommodation, the activities carried out during the vacation and the services and/or resources used (water, waste, energy, transportation, etc.) (Figure 1).

Since tourism is a composite product, the LCA of a tourism product begins when the tourist starts the trip and ends when the tourist returns home. According to this "door-todoor" concept, LCA is used to assess all environmental impacts generated when the tourist is away from home. However, to analyze every impact cost of every aspect of a holiday, from preparatory to return activities, is a prohibitively exhaustive process. Therefore, the authors determined a more realistic scope. Primarily LCA was limited to aspects of the holiday with which tourists came into personal contact. For this reason, this paper cut off the construction and destruction phase of the accommodation facilities because this could detract from the focus of the assessment that is entirely cantered on the holiday package purchased by a tourist. Secondary considering that the methodology proposed by the authors wants to be a valid support for public administrations in sustainable tourism planning, pre- and post-trip activities are excluded. This because local authorities can do 
little to guide these stages that are part of a more global vision of the tourism product. For this reason, the methodology proposed by the author for the LCA of a tourism product combine different transportation option with each possible accommodation and activity offered by a tourist destination. Specifically, it is recommended that public administration use LCA to direct tourists towards responsible behavior suggesting tourists which are the more sustainable means of transports, places to sleep and activities to do. This means that the LCA application should focus on the best means to reach the desired destination, the less harmful activities and how to get local accommodations greener. In order to calculate the LCA linked to the operation of each of the different types of accommodation, the use of water, electricity, and methane were included among the inputs and the production of solid waste has been considered as an output (Table 1). Among the outputs it has not been possible to take into consideration the waste water because in literature there are not sufficient data about it.

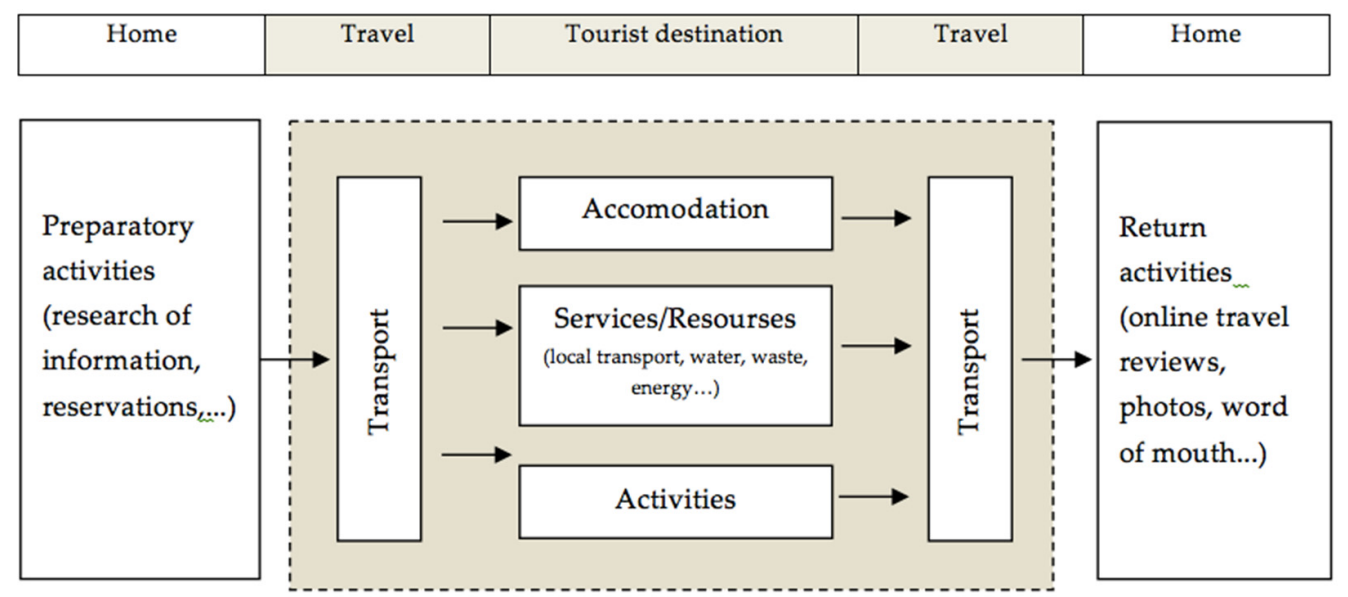

Figure 1. Boundary system chosen for the calculation of the LCA of the tourism product in its entirety: from the activities preparatory to the trip to those of return. Source: authors.

Table 1. Inputs and output related to accommodations according to the authors' methodology.

\begin{tabular}{ccc}
\hline INPUT & OUTPUT \\
\hline Water & $1-2$ stars hotel & \\
Energy & 3 stars hotel & Solid waste \\
Methane & $4-5$ stars hotel & \\
& B \& B & \\
\hline
\end{tabular}

Generally, the resources used for the operation of the facilities are considered as inputs and the discarded materials as outputs.

To calculate the LCA of the total tourism product each different transportation option is combined with each possible accommodation and activity choice. Finally, the authors suggest to use the software Simapro, one of the leading software to collect, analyze, and monitor the environmental performance of products and services.

\section{Results: The Cinque Terre Case Study Application}

Case study and first application of the proposed methodology is the Cinque Terre National Park, the first tourist destination of the Liguria Region in Italy (Figure 2). The use of the case study is employed in many situations to contribute to specific knowledge or a group of situations related to the case itself. Focusing on an individual case allows for a holistic and real-world perspective to be maintained [87]. In particular, the chosen case is considered replicable in many other tourist destinations, especially in the Mediterranean area, characterized by 


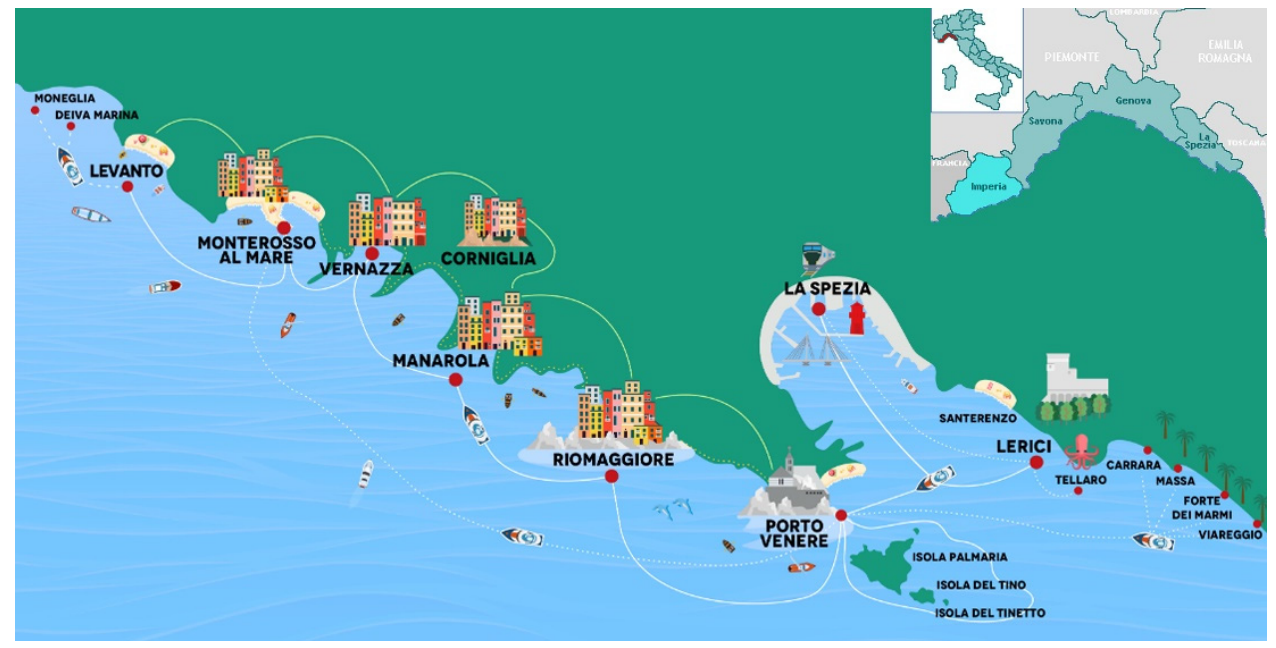

Figure 2. Tourist map produced by the La Spezia tourist office. The Cinque Terre (Monterosso, Vernazza, Corniglia, Manarola, and Riomaggiore) are in Italy, Liguria Region, La Spezia Province.

- $\quad$ Historical centers with narrow streets and small housing units;

- Valuable natural terrestrial areas

- $\quad$ Protected marine areas;

- $\quad$ Land with ancient crops;

- Communities with ancient traditions;

- Villages connected by narrow, winding streets.

The Mediterranean area is the most visited area in the world, so it is important to start from here to study new solutions for a more sustainable tourism. The Cinque Terre, a worldfamous tourist destination, is a fragile area from a hydrogeological and environmental point of view compared to many other Mediterranean destinations, which can hardly cope with the flow of 3.5 million tourists arriving every year. Despite the obvious signs of distress, the model of maximizing tourism is still being pursued here. Extreme weather phenomena, senseless exploitation of the land and unbridled tourism are threatening one of the most special and difficult places on the Italian coast. To save this heritage of beauty and biodiversity, public authorities need to rethink the relationship between tourism and the environment. For this reason, it was decided to use this emblematic case study as a starting point to provide local municipalities with new tools for assessing the environmental impacts of tourism in order to define new strategies and planning tools.

The Cinque Terre are five colorful villages (Monterosso, Vernazza, Corniglia, Manarola, and Riomaggiore) overlooking the sea on the eastern Ligurian Riviera. With their vineyards, vegetable gardens, and mountain backdrops, they are part of a national park much loved by both Italian and international tourists. The Cinque Terre are a special place, but they are in danger of being lost because of a fragile territory prone to flooding and landslides and the excessive number of visitors. These villages are increasingly turning into one of the many places where people live only to serve tourism, compromising their quality and beauty and above all their authenticity. The ever-increasing flow of tourists has seriously threatened the economic, ecological, and cultural balance of the park. To move from one village to another, visitors must take the train because there is no road connection. This is leading to an unsustainable situation where trains and railway stations are always too crowded.

Following the logic of LCA, the tourism product is evaluated in its entirety, as a complete experience of a tourist from home to home according to the boundary system described in the previous chapter that cut off the pre and post trip activities. According to this "door to door" concept the LCA is used to assess all environmental impacts generated when the tourist is away from home. The starting point considered is within a radius of $1.000 \mathrm{~km}$ (Paris, Barcelona, Berlin, Prague, etc.) and the end is the Cinque Terre National Park. The construction phase of the accommodation facilities was excluded, as stated in 
the methodology chapter, because this could detract from the focus of the assessment that is entirely center on the holiday package purchased by a tourist. The functional considered is a temporal unit: one person spending 3 days' holiday inside the Cinque Terre National Park. This time span was chosen because, excluding cruise tourists who on average stay only half a day, it is the average time spent by visitors to the Cinque Terre Park. Thanks to this functional unit it is possible to compare different holiday packages according to the means of transportation used to reach the destination, the type of accommodation and the leisure activities undertaken during the visit (Table 2).

Table 2. The relevant alternative solutions related to the product under study. Source: authors.

$\begin{array}{ccc} & \text { Accommodation } & \\ & 1-2 \text { star hotel } & \\ & 3 \text { star hotel } & \\ \text { Outward trip } & 4-5 \text { star hotel } & \text { Return trip } \\ \text { plane } & \text { B\&B } & \text { plane } \\ \text { bus } & \text { Apartment } & \text { bus } \\ \text { cruise } & \text { Activities } & \text { cruise } \\ \text { private car } & \text { Sight seeing } & \text { private car } \\ \text { bike } & \text { Hiking } & \text { bike } \\ & \text { Boat tour } & \\ & \text { Diving } & \\ & \text { Jet ski } & \\ & \text { Swimming pool } & \\ & \text { Sauna, etc. } & \end{array}$

The LCA of each travel possibility was calculated using the Simapro software. The impact categories used by the authors to asses tourist options are: Climate change; Human toxicity; Acidification; Terrestrial Eutrophication; Ozone formation; and Resources. Primary and secondary data come from publications (Table 3), open literature, LCA libraries and tourism statistics office.

Table 3. The main references used for data collection.

\begin{tabular}{ll}
\hline Source & Object and Location \\
\hline Rossello Batle et al. (2010) & 2 hotels in the Balearic Island, Spain \\
Dascalki and Balaras (2004) & 4 hotels in France, Greece, Italy, and Spain \\
De Camillis et al. (2008-2010) & 3 budget hotels in Italy \\
Filimonau et al. (2013) & A journey in southern France \\
Konig et al. (2007) & Tourism resort in Portugal \\
Karagiorgas et al. (2006) & 200 hotels in Greece, Italy, France, and Spain \\
Sala and Catellani (2012) & One week holiday in Italy \\
Xydis et al. (2009) & 4 hotels in Greece \\
\hline
\end{tabular}

With regard to the INPUT data, i.e., the resources used, and OUTPUT data of the different accommodation facilities, the authors systematized the information contained in different publications (Table 3 ) and reworked it in the following table (Table 4).

Table 4. Data use by the authors for LCA of different accommodation facilities.

\begin{tabular}{clcccc}
\hline \multicolumn{7}{c}{ Accommodation Data } \\
\hline INPUT & UNIT & 1-2 Star & 3 Star & 4-5 Star & B\&B \\
\hline electricity & Kwh*guest/night & 5.1 & 1.4 & 26 & 4.7 \\
natural gas & Kwh*guest/night & 4.1 & 6.1 & 13 & 7.8 \\
water & l*guest/night $^{*}$ & 335 & 380 & 480 & 350 \\
\hline OUTPUT & UNIT & $\mathbf{1 - 2 ~ S t a r}$ & 3 Star & 4-5 Star & B\&B \\
\hline solid waste & Kwh*guest/night & 0.56 & 0.8 & 1 & 0.6 \\
\hline
\end{tabular}


In order to assess the life cycle assessment of the various means of transport, the databases available in the Simapro software for the countries of the European Union were used. All the collected data for the different types of accommodation and transportation were organized referring to the functional unit: one person spending three nights inside the Cinque Terre National Park. This is not the case for the activities carried out during the holiday, which were only considered once as they are valid as a single experience. A tourist who decides to take a boat trip in the park is unlikely to repeat the same activity the next day. For this reason, a combined analysis of the three days' stay in the Cinque Terre Park of the means of transport and accommodation is given first, while the activities carried out on holiday are analyzed individually.

The following tables show the environmental impacts for each of the selected categories (Climate change; Human toxicity; Acidification; Terrestrial Eutrophication; Ozone formation; and Resources) related to the different means of transport (Table 5) and types of accommodation (Table 6). In the graphs, however, the data obtained were maximized taking into account the highest recorded value in order to be able to compare the different impacts depending on the means of transport (Figure 3) and the accommodation facility (Figure 4). Analyzing the results obtained, it is clear that the worst combination from an environmental point of view is the travel solution that considers a $4-5$ star hotel and travel by car (always taking into account the functional unit of a person for 5 nights). Instead, the most environmentally friendly solution is to travel by train and sleep in a 1-2 star hotel. It is interesting to note that the solution of sleeping in a $B \& B$ and traveling by bus is very similar in terms of impacts to the more sustainable choice. The bus appears to have a greater contribution than the train in terms of acidification, global warming, ozone layer depletion, and abiotic depletion of fossil fuels; almost equal for eutrophication and photochemical oxidation and better for abiotic depletion. The travel solution that includes an overnight stay in a B\&B differs little from that in a 1-2 star hotel, and both can be considered as virtuous choices by local administrations.

Table 5. Data related to transport LCA for the case study.

\begin{tabular}{cccccc}
\hline $\begin{array}{c}\text { Tourism Transport } \\
\text { Solution/Impact }\end{array}$ & Aircraft & Car & Coach & Train & Max \\
\hline Acidification kg SO2 eq & 1.17 & 1.76 & 0.709 & 0.413 & 1.76 \\
\hline $\begin{array}{c}\text { Eutrophication } \\
\text { kg PO4-eq }\end{array}$ & 0.187 & 0.541 & 0.138 & 0.137 & 0.541 \\
\hline $\begin{array}{c}\text { Global } \\
\text { warming (GWP 100a) kg } \\
\text { CO2 eq }\end{array}$ & 271 & 633 & 94.2 & 81.6 & 633 \\
\hline $\begin{array}{c}\text { Photochemical Oxidation } \\
\text { kg C2H4 eq }\end{array}$ & 0.0431 & 0.17 & $1.81 \times 10^{-2}$ & $2.01 \times 10^{-2}$ & 0.17 \\
\hline $\begin{array}{c}\text { Ozone layer depletion } \\
\text { kg CFC-11 eq }\end{array}$ & $5 \times 10^{-5}$ & $9.67 \times 10^{-5}$ & $1.68 \times 10^{-5}$ & $9.11 \times 10^{-6}$ & $9.70 \times 10^{-5}$ \\
\hline $\begin{array}{c}\text { Abiotic depletion } \\
\text { kg Sb eq }\end{array}$ & $2.27 \times 10^{-5}$ & $7.25 \times 10^{-3}$ & $1.50 \times 10^{-5}$ & $3.21 \times 10^{-4}$ & $7.25 \times 10^{-3}$ \\
\hline $\begin{array}{c}\text { Fossil fuels } \\
\text { Mj }\end{array}$ & $3.90 \times 10^{-3}$ & $8.53 \times 10^{-3}$ & $1.37 \times 10^{-3}$ & 910 & $8.53 \times 10^{-3}$ \\
\hline
\end{tabular}

Table 6. Data related to transport LCA for the case study.

\begin{tabular}{cccccc}
\hline $\begin{array}{c}\text { Accomodation/Max } \\
\text { Impact }\end{array}$ & 1-2 Stars & 3 Stars & 4-5 Stars & B\&B & Max \\
\hline $\begin{array}{c}\text { Acidification kg } \\
\text { SO2 eq }\end{array}$ & 0.249 & 0.5939 & 1 & 0.1942 & 0.369 \\
\hline $\begin{array}{c}\text { Eutrophication } \\
\text { kg PO4—eq }\end{array}$ & 0.2211 & 0.5518 & 1 & 0.2122 & 0.0847 \\
\hline
\end{tabular}


Table 6. Cont.

\begin{tabular}{|c|c|c|c|c|c|}
\hline $\begin{array}{l}\text { Accomodation/Max } \\
\text { Impact }\end{array}$ & 1-2 Stars & 3 Stars & 4-5 Stars & $B \& B$ & Max \\
\hline $\begin{array}{c}\text { Global } \\
\text { warming (GWP } \\
\text { 100a) kg CO2 eq }\end{array}$ & 0.2316 & 0.5489 & 1 & 0.2452 & 56.493 \\
\hline $\begin{array}{c}\text { Photochemical } \\
\text { Oxidation } \\
\text { kg C2H4 eq }\end{array}$ & 0.2121 & 0.5434 & 1 & 0.2100 & 0.0151 \\
\hline $\begin{array}{l}\text { Ozone layer } \\
\text { depletion } \\
\text { kg CFC-11 eq }\end{array}$ & 0.2111 & 0.5389 & 1 & 0.2143 & $642 \times 10^{-6}$ \\
\hline $\begin{array}{l}\text { Abiotic depletion } \\
\text { kg Sb eq }\end{array}$ & 0.2201 & 0.5501 & 1 & 0.2133 & 0.0001 \\
\hline $\begin{array}{l}\text { Fossil fuels } \\
\text { Mj }\end{array}$ & 0.2199 & 0.5349 & 1 & 0.2412 & 576.10 \\
\hline
\end{tabular}

Abiotic depletion, fossil...

Abiotic depletion

Ozone layer depletion

Photoochemical oxidation

Global warming...

Eutrophication

Acidification

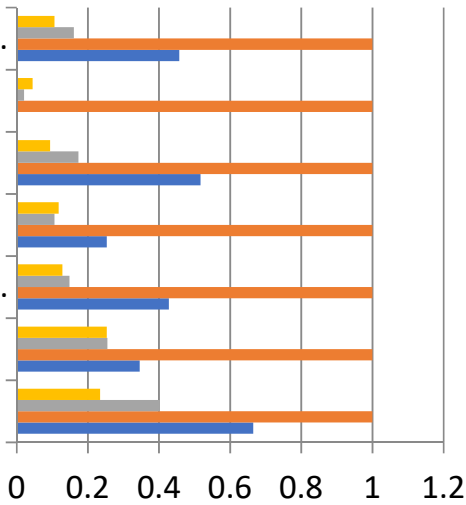

Tourist journey(train)

Tourist journey (coach)

- Tourist journey (car)

Tourist journey (aircraft)

Figure 3. LCA related to tourism transport means for the case study.

Abiotic depletion, fossil fuels $\mathrm{Kg}$

Abiotic depletion

Ozone layer depletion

Photoochemical oxidation

Global warming..

Eutrophication

Acidification

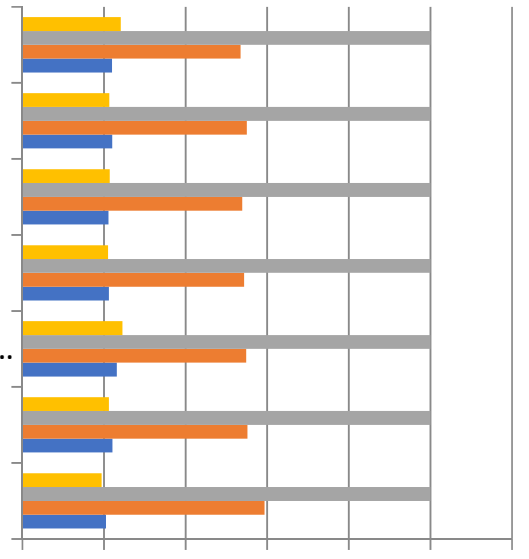

B\&B

4-5 STARS

3 STARS

1-2 STARS

Figure 4. LCA related to tourism accommodation for the case study.

With respect to accommodation, the greatest effects on the environment are due to the use of electricity for each of the global and regional environmental impacts considered (global warming, ozone depletion, abiotic depletion, acidification, eutrophication, and photochemical oxidation). It can therefore be said that the first operation to be carried out by local authorities is to reduce the impacts linked to the accommodation facilities investing in energy efficiency of the buildings. Secondly, interventions to reduce heat loss and water consumption are important. These interventions can be carried out through a publicprivate partnership. The public sector, for example, can help with its own technicians to 
assess the state of the building from the point of view of energy and heat performance, and can also help building owners to access national and European funding. In addition, local authorities can provide a sustainable tourism plan that also takes into account the state of existing accommodation facilities and aims to reduce waste.

However, the negative environmental effects do not derive only from the type of transport or of accommodation but also from the activities carried out by tourists during their journey. The greatest impacts are related to activities that consume fuel or electricity and much depends on the number of people who can perform the same activity at the same time (the higher the number of people, the lower is the impact). According to the LCA the jet skiing is the activity carried out in the Cinque Terre that produces the most negative effects on the environment while hiking is the most sustainable. The second least impactful activity is the sightseeing between one village and another moving by train, while the penultimate activity in terms of impacts is the boat tour. The sea activities to be considered sustainable are snorkeling, canoeing, and stand-up paddle. The graph below (Figure 5) reports the environmental impacts of the land and marine activities considered using a reference scale of 1 to 20 , where 1 is the minimum impact and 20 the maximum impact. Taking into account the results obtained, local administrations should promote less impactful activities more, e.g., by better signposting the park's hiking network and by trying to convert more impactful marine activities such as jet ski to other activities such as snorkeling or canoeing. Certainly, local sustainable development tourism plans should prevent private companies starting new high impact activities inside the park area.

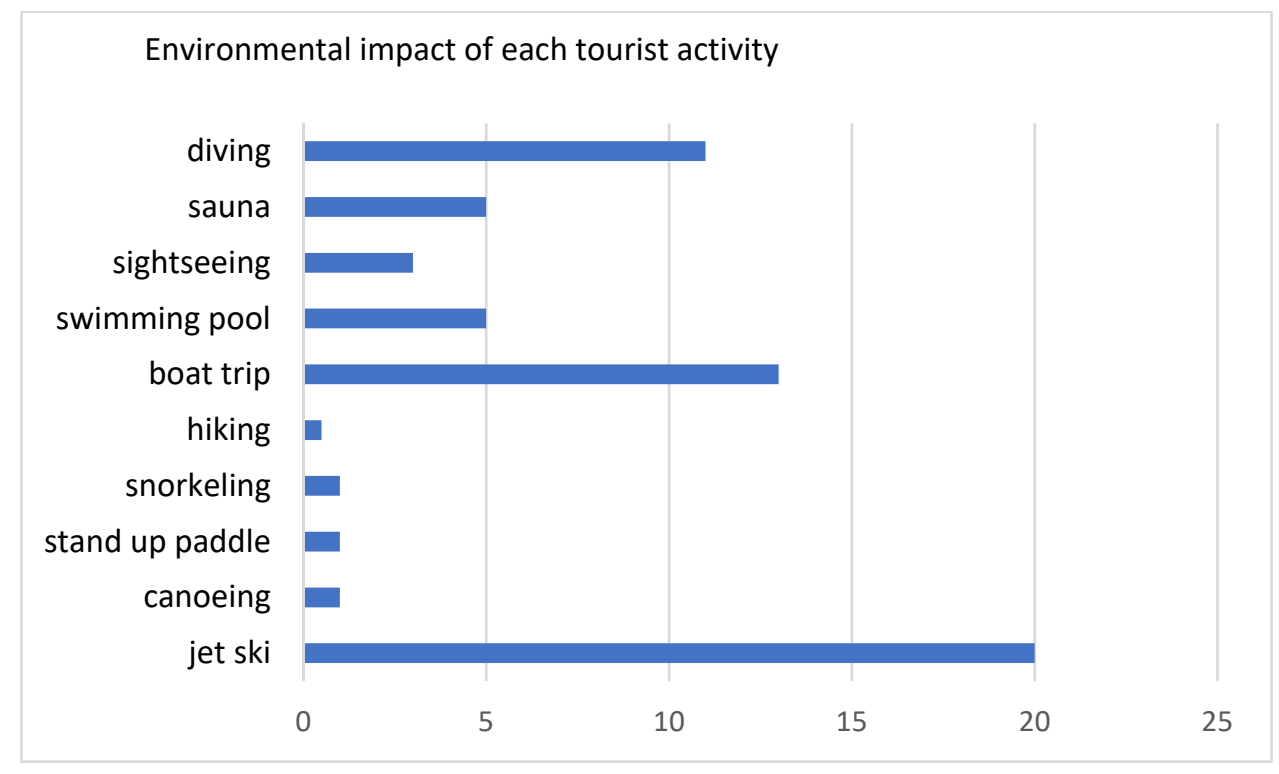

Figure 5. LCA Environmental impact related to activities in the Cinque Terre. For the boat tour activity was considered a boat with a capacity of fifty people.

Furthermore, on the basis of LCA results, public administrations can provide practical guidelines for accommodation facilities owners, tourism activity organizers or other important stakeholders. These guides should indicate the solutions to be adopted to reduce the environmental impacts related to the analyzed tourist product or facility. Thanks to LCA it is possible to identify the most impactful elements/processes and to evaluate alternative solutions. In the table below the authors give an example of practical guidelines for managers of accommodation facilities (Table 7). 
Table 7. Guidelines to reduce environmental impacts of accommodation facilities.

\begin{tabular}{lc}
\hline \multicolumn{1}{c}{ Guidelines for Accommodation Facilities Owners } \\
\hline Energy-savings & Recommended Interventions \\
& Install light sensors and solar panel \\
Switch to LED Lights \\
Reduce settings on Air Conditioner
\end{tabular}

\section{Discussion}

The paper seeks to develop a new methodology for public authorities to assess the environmental impacts of tourism. These impacts have to be taken into account within the planning tools for the promotion of sustainable tourism. However, there are still many aspects to be considered. In fact, the study is limited to assessing the environmental impacts linked to the type of accommodation, transport, and activities chosen by tourists during their stay. The paper does not dwell on the economic and social aspects, both of which are important if the concept of sustainability is to be analyzed comprehensively. To overcome these limitations, for example, it could be useful to weigh the results achieved through the LCA with economic parameters in order to take into account the positive effects of the tourism industry on GDP in host communities. Correction factors could be included for each of the means of transport, types of accommodation, and activities undertaken during the holiday. The social aspects of sustainability should also be further analyzed. In this case, it could be envisaged to create and distribute a questionnaire to understand the relationship between the residents of the visited destination and the tourists.

Sustainability comes from balancing its three components: economic, environmental, and social. This paper, analyzing the tourism industry, has focused on the environmental component, since all too often local plans and policies only consider only the economic returns of tourism [88-90]. While there are numerous studies in the literature on tourism from an economic point of view, environmental impacts have only been analyzed in the last 10 years and there is still no agreed methodology on how to evaluate them scientifically. The use of LCA methodology applied to tourism was introduced in 2010 by De Cammillis et al. [91,92] and has been followed by other interesting studies on the subject [93-95]. However, there is currently no predominant or codified methodology on the use of LCA in the tourism sector. This paper seeks to contribute to this debate by proposing a simple and replicable way (especially by public administrations) of using LCA to assess the environmental impacts of accommodation, transport, and activities chosen by tourists in a destination.

Alternative methods to LCA for assessing tourism-related environmental impacts also exist in the literature. Very interesting are the studies by Gossling and Peters [96] on resource consumption by tourism (fossil fuel consumption, associated $\mathrm{CO} 2$ emissions, fresh water, land, and food use) using the Global Tourism Transport Model to understand past and future resource consumption related to the tourism sector. This model is based on the calculation of RUI-resource use intensities, i.e., the difference between the quantity of input against the quantity of output. Another methodology for assessing the environmental impacts of tourism is related to the calculation of Tourist Carrying Capacity in 
park/protected areas, i.e., the maximum number of visitors an ecosystem can support without having significant negative impacts $[97,98]$. However, it is true that in order to achieve comprehensive results, it is necessary to assess all aspects of sustainability at the same time. One solution could be for public administrations to evaluate the results obtained from this paper in conjunction with interesting studies that have come out in recent years that quantify the social [99-102] and economic [103-105] impacts.

A further aspect that deserves to be explored is innovation in the tourism sector. This innovation can be linked to the use of technology and ICT tools [106] but also to new models of analysis [107] or management to improve the hospitality of a destination [108]. In all three cases, it is important to focus on creativity and a close collaboration between public and private sectors. Tourism is a fast-growing sector and in order to remain competitive, destinations must focus on innovation in their tourist offer. Advances in technology can not only improve tourism products and services, but also steer the sector towards responsible choices. ICT tools and applications can contribute to the spread of sustainable tourism services, responding to a new awareness towards the environment and host communities. For this reason, it can also be hypothesized that the results obtained by applying the LCA methodology to tourism products (proposed in the paper) can be viewed in real time by tourists via smartphone. In this way it is possible to make them aware of the choice of the most sustainable means of transport, accommodation, and activities in a destination.

\section{Conclusions}

Current quantity-based development models and the projected growth of the global tourism industry will continue to damage landscapes, cause soil erosion, put pressure on species, further strain available water resources, increase waste and pollution discharges into the sea, and lead to cultural unrest [109]. The need for tourist sustainability should not be underestimated: in fact, more and more destinations are experiencing the negative effects of a fast-growing phenomenon, capable of registering a global increase of $7 \%$ per year [110]. The crisis of the tourism sector due to the COVID pandemic represents an opportunity that allows the development of more efficient and sustainable services to meet the demands of increasingly aware and attentive travelers.

The methodology proposed by the paper is of great interest because the first reopening of local and international borders has shown how tourism is an indispensable need for many. The beaches, as well as the cities of art, have once again filled with visitors ready to crowd in, despite the many bans imposed to decrease the risk of contagion. This shows how the necessity of a sustainable tourism is a very real issue. The economic models on which the tourism industry were predominantly based before the advent of COVID were unsustainable, unable to meet the 2030 Agenda goals and the 2050 climate neutrality required by the European Union. This is why a change in course and a real turnaround in support of sustainable tourism is essential. Thanks to the LCA methodology, it is possible to reduce the consumption of local resources (for example, by improving thermal and energy performance of accommodation facilities) and identify the most sustainable transportation systems and tourism activities of a destination. However, the method proposed in the paper must be integrated into local policies and planning tools for promoting sustainable tourism. Without this practical aspect it risks remaining a theoretical tool unable to bring about real change in the tourism sector. Many Italian municipalities suffering from mass tourism should adopt sustainable tourism plans that analyze how to reduce the negative impacts of this economic sector on the environment and host communities. This plan would also be useful for tourist municipalities that have not yet reached saturation levels, in order to steer the development of the sector towards sustainable choices and avoid making the same mistakes made in other places. At present, in Italy, tourism planning stops at the regional level, except in a few rare cases such as Venice. Other European countries have instead supported and developed various plans at local level. In Spain, for example, there are many municipal tourism plans. In this case, the municipal level has been able to produce interesting results by better distributing tourism throughout the territory thanks to the 
diversification of the tourist offer. Believing in the importance of tourism planning at a local level, the paper seeks to provide additional scientific tools to all municipalities that decide to implement their own plan to support sustainable tourism. In particular, the proposed method helps planners to quantify the environmental impacts of tourism in a destination. Once the impacts have been quantified, local governments can make decisions in their plans to promote the most sustainable solutions. The application of the methodology to a typical case study for the Mediterranean area further helps administrations to transfer and replicate the authors' proposal. The results obtained from the application of the methodology proposed in the paper show that the impacts of transport are at least five times higher than those of accommodation for all categories considered (global warming, ozone depletion, abiotic depletion, acidification, and photochemical oxidation) except for the values concerning eutrophication. In addition, it was found that the most environmentally friendly solution is to travel by train and sleep in a 1-2 star hotel, but it is interesting to note that the solution sleeping in a B\&B and travel by bus is very similar in terms of impacts to the more sustainable choice. The results obtained are also valid for other areas in the Mediterranean as the authors used European databases to evaluate means of transport and data from Spain, France, Italy, and Greece for accommodation facilities. In order to evaluate case studies in northern Europe, it is necessary to retrieve the resource consumption of hotels in other countries as it can vary considerably (just think of heating) compared to the Mediterranean area. The same applies to the activities/experiences tourists can participate in at the destination under study. The activities analyzed in the paper are in fact typical for coastal locations in the Mediterranean: boat trips, jet-ski, hiking, snorkeling, diving, canoeing, etc. Overall, we can say that the study has achieved the objectives set out in the introduction, namely, to contribute to making tourism more sustainable in the postCOVID era. Thanks to the proposed methodology, public administrations can assess the environmental impacts of tourism and propose greener choices.

Author Contributions: Conceptualization, S.C. and F.P.; methodology, F.P.; software, S.C.; validation, S.C. and F.P.; formal analysis, F.P.; writing-original draft preparation, S.C.; writing-review and editing, S.C.; supervision, F.P. All authors have read and agreed to the published version of the manuscript.

Funding: This research received no external funding.

Institutional Review Board Statement: Not applicable.

Informed Consent Statement: Not applicable.

Data Availability Statement: The data presented in this study are openly available in Figshare at https:/ / doi.org/10.6084/m9.figshare.17298641.v1.

Conflicts of Interest: The authors declare no conflict of interest.

\section{References}

1. Birendra, K.C.; Adity, D.; Tek, B.D. Tourism and the sustainable development goals: Stakeholders' perspectives from Nepal. Tour. Manag. Perspect. 2021, 38, 100822.

2. Khan, M.A. Tourism in Turkey, 1st ed.; Apple Academic Press: Burlington, ON, Canada, 2021; pp. 17-18.

3. Xudoyarov A., A. The role of visiting tourism in the peculiarities and aspects of the tourism industry in the global markets. Am. J. Econ. Bus. Manag. 2019, 2, 180-190.

4. Mathew, P.V.; Kuriakose, V. A Study on the Indicator Framework of Responsible Tourism in Tourism Accommodation Sector. Asian J. Manag. 2017, 8, 989-996. [CrossRef]

5. UNWTO. Tourism Highlights; UNWTO: Madrid, Spain, 2018.

6. Elliott, J. Tourism: Politics and Public Sector Management; Routledge: London, UK, 2020.

7. Sofronov, B. The development of the travel and tourism industry in the world. Ann. Spiru Haret Univ. -Econ. Ser. 2018, 18, 123-137. [CrossRef]

8. Ţîţu, M.A.; Răulea, A.S.; Ţîţu, Ş. Measuring service quality in tourism industry. Procedia-Soc. Behav. Sci. 2016, 221, 294-301. [CrossRef]

9. Ayres, R. Tourism as a passport to development in small states: Reflections on Cyprus. Int. J. Soc. Econ. 2000, 27, 114-133. [CrossRef]

10. D’Eramo, M. Il Selfie del Mondo: Indagine sull'età del Turismo; Feltrinelli Editore: Milan, Italy, 2019. 
11. Del Vecchio, P.; Passiante, G. Is tourism a driver for smart specialization? Evidence from Apulia, an Italian region with a tourism vocation. J. Destin. Mark. Manag. 2017, 6, 163-165. [CrossRef]

12. Ursache, M. Tourism-significant driver shaping a destinations heritage. Procedia-Soc. Behav. Sci. 2015, 188, 130-137. [CrossRef]

13. Croce, V. With growth comes accountability: Could a leisure activity turn into a driver for sustainable growth? J. Tour. Futures 2018, 4, 218-232. [CrossRef]

14. De Lucia, C.; Pazienza, P.; Balena, P.; Caporale, D. Exploring local knowledge and socio-economic factors for touristic attractiveness and sustainability. Int. J. Tour. Res. 2020, 22, 81-99. [CrossRef]

15. OECD. Tourism Trends and Policies; OECD: Paris, France, 2020.

16. Abbas, J.; Mubeen, R.; Iorember, P.T.; Raza, S.; Mamirkulova, G. Exploring the impact of COVID-19 on tourism: Transformational potential and implications for a sustainable recovery of the travel and leisure industry. Curr. Res. Behav. Sci. 2021, 2, 100033. [CrossRef]

17. Lew, A.A.; Cheer, J.M.; Haywood, M.; Brouder, P.; Salazar, N.B. Visions of travel and tourism after the global COVID-19 transformation of 2020. Tour. Geogr. 2020, 8, 455-466. [CrossRef]

18. Folinas, S.; Metaxas, T. Tourism: The Great Patient of Coronavirus COVID-2019. Int. J. Adv. Res. 2020, 4, 365-375. [CrossRef]

19. Lapointe, D. Reconnecting tourism after COVID-19: The paradox of alterity in tourism areas. Tour. Geogr. 2020, 22, 633-638. [CrossRef]

20. COVID-19 and Tourism, an Update; United Nation Conference on Trade and Development, 2021; Available online: https: / unctad. org/system/files/official-document/ditcinf2021d3_en_0.pdf (accessed on 18 December 2021).

21. Rajapaksha, K. COVID-19 and Tourism. 2021. Available online: https://papers.ssrn.com/sol3/papers.cfm?abstract_id=3909608 (accessed on 18 December 2021).

22. Crossley, É. Ecological grief generates desire for environmental healing in tourism after COVID-19. Tour. Geogr. 2020, 22, 536-546. [CrossRef]

23. Nepal, S.K. Adventure travel and tourism after COVID-19-business as usual or opportunity to reset? Tour. Geogr. 2020, 22, 646-650. [CrossRef]

24. Kusumaningrum, D.A.; Wachyuni, S.S. The shifting trends in travelling after the COVID 19 pandemic. Int. J. Tour. Hosp. Rev. 2020, 7, 31-40. [CrossRef]

25. Miao, L.; Im, J.; Fu, X.; Kim, H.; Zhang, Y.E. Proximal and distal post-COVID travel behavior. Ann. Tour. Res. 2021, 88, 103159. [CrossRef]

26. Prayag, G. Time for reset? COVID-19 and tourism resilience. Tour. Rev. Int. 2020, 24, 179-184. [CrossRef]

27. Okafor, L.E.; Khalid, U.; Burzynska, K. Does the level of a country's resilience moderate the link between the tourism industry and the economic policy response to the COVID-19 pandemic? Curr. Issues Tour. 2021, 1-16. [CrossRef]

28. Peco-Torres, F.; Polo-Peña, A.I.; Frías-Jamilena, D.M. The effect of COVID-19 on tourists' intention to resume hotel consumption: The role of resilience. Int. J. Hosp. Manag. 2021, 99, 103075. [CrossRef]

29. Garcia, B.M. Integrating culture in post-crisis urban recovery: Reflections on the power of cultural heritage to deal with crisis. Int. J. Disaster Risk Reduct. 2021, 60, 102277. [CrossRef]

30. Mini, V. Turismo lento come risposta alla convivenza con il COVID-19. Ann. Del Tur. 2021, 11, 107-111.

31. Lenzi, M. Turismo e COVID-19: Tra Criticità e Innovazione di un Turismo Anticonvenzionale. Bachelor's Thesis, Università Ca'Foscari Venice, Venice, Italy, 2020.

32. Romagosa, F. The COVID-19 crisis: Opportunities for sustainable and proximity tourism. Tour. Geogr. 2020, 22, 690-694. [CrossRef]

33. Fletcher, R.; Murray, I.; Blázquez-Salom, M.; Asunción, B.R. Tourism, degrowth, and the COVID-19 Crisis. Political Ecol. Netw. 2020, 24, 223-227.

34. Higgins-Desbiolles, F. The "war over tourism": Challenges to sustainable tourism in the tourism academy after COVID-19. J. Sustain. Tour. 2020, 29, 551-569. [CrossRef]

35. Pepe, A.; Percoco, A. Passato-futuro: La legacy turistica di Matera 2019 dopo il COVID-19. Ann. Del Tur. 2021, 11, 89-106.

36. Duro, J.A.; Perez-Laborda, A.; Turrion-Prats, J.; Fernández-Fernández, M. COVID-19 and tourism vulnerability. Tour. Manag. Perspect. 2021, 38, 100819. [CrossRef] [PubMed]

37. Galvani, A.; Lew, A.A.; Perez, M.S. COVID-19 is expanding global consciousness and the sustainability of travel and tourism. Tour. Geogr. 2020, 22, 567-576. [CrossRef]

38. Aref, F.; Gill, S.S.; Aref, A. Assessing the level of community capacity building in tourism development in local communities. J. Sustain. Dev. 2010, 3, 81. [CrossRef]

39. Saarinen, J. Communities and sustainable tourism development: Community impacts and local benefit creation in tourism. In A Research Agenda for Sustainable Tourism; Edward Elgar Publishing: Camberley, UK, 2019.

40. Amerta, I.M.S.; Sara, I.M.; Bagiada, K. Sustainable tourism development. Int. Res. J. Manag. IT Soc. Sci. 2018, 5, 248-254. [CrossRef]

41. Pirlone, F.; Spadaro, I. Sustainable tourism action plan in the Mediterranean coastal areas. Int. J. Sustain. Dev. Plan. 2017, 12, 995-1005. [CrossRef]

42. Ruhanen, L. Progressing the sustainability debate: A knowledge management approach to sustainable tourism planning. Curr. Issues Tour. 2008, 11, 429-455. [CrossRef]

43. Choi, H.C.; Sirakaya, E. Sustainability indicators for managing community tourism. Tour. Manag. 2006, 27, 1274-1289. [CrossRef] 
44. Simão, J.N.; Partidário, M.D.R. How does tourism planning contribute to sustainable development? Sustain. Dev. 2012, 20, 372-385. [CrossRef]

45. Balsalobre-Lorente, D.; Driha, O.M.; Shahbaz, M.; Sinha, A. The effects of tourism and globalization over environmental degradation in developed countries. Environ. Sci. Pollut. Res. 2020, 27, 7130-7144. [CrossRef]

46. Pigram, J.J. Alternative tourism: Tourism and sustainable resource management. In Tourism Alternatives; University of Pennsylvania Press: Philadelphia, PA, USA, 2016; pp. 76-87.

47. Ghosh, S. Effects of Tourism on Carbon Dioxide Emissions, a Panel Causality Analysis with New Data Sets; Environment, Development and Sustainability: Dordrecht, The Netherlands, 2021; pp. 1-23.

48. Hall, C.M. Heritage, heritage tourism and climate change. J. Herit. Tour. 2016, 11, 1-9. [CrossRef]

49. Eijgelaar, E.; Peeters, P. The Global Footprint of Tourism. In The Wiley Blackwell Companion to Tourism; John Wiley \& Sons: Chichester, UK, 2014; pp. 454-465. Available online: https://onlinelibrary.wiley.com/doi/book/10.1002/9781118474648 (accessed on 18 December 2021).

50. Gössling, S. National emissions from tourism: An overlooked policy challenge? Energy Policy 2013, 59, 433-442. [CrossRef]

51. Gössling, S.; Peeters, P.; Ceron, J.P.; Dubois, G.; Patterson, T.; Richardson, R.B. The eco-efficiency of tourism. Ecol. Econ. 2005, 54, 417-434. [CrossRef]

52. McKercher, B.; Prideaux, B. Are tourism impacts low on personal environmental agendas? J. Sustain. Tour. 2011, 19, 325-345. [CrossRef]

53. Hsieh, H.J.; Kung, S.F. The linkage analysis of environmental impact of tourism industry. Procedia Environ. Sci. 2013, 17, 658-665. [CrossRef]

54. Furqan, A.; Som, A.P.M.; Hussin, R. Promoting green tourism for future sustainability. Theor. Empir. Res. Urban Manag. 2010, 58, 64-74.

55. Zhong, L.; Deng, J.; Song, Z.; Ding, P. Research on environmental impacts of tourism in China: Progress and prospect. J. Environ. Manag. 2011, 92, 2972-2983. [CrossRef] [PubMed]

56. Scott, D. Why sustainable tourism must address climate change. J. Sustain. Tour. 2011, 19, 17-34. [CrossRef]

57. Buckley, R. Sustainable tourism: Research and reality. Ann. Tour. Res. 2012, 39, 528-546. [CrossRef]

58. De Camillis, C.; Raggi, A.; Petti, L. Tourism LCA: State-of-the-art and perspectives. Int. J. Life Cycle Assess. 2010, 15, 148-155. [CrossRef]

59. Romeril, M. Tourism and the environment-Accord or discord? Tour. Manag. 1989, 10, 204-208. [CrossRef]

60. Gössling, S.; Peeters, P. 'It does not harm the environment!' An analysis of industry discourses on tourism, air travel and the environment. J. Sustain. Tourism 2007, 15, 402-417. [CrossRef]

61. Zhang, J.; Zhang, Y. Carbon tax, tourism $\mathrm{CO}_{2}$ emissions and economic welfare. Ann. Tour. Res. 2018, 69, 18-30. [CrossRef]

62. Candia, S.; Pirlone, F.; Spadaro, I. Sustainable development and the plan for tourism in Mediterranean coastal areas: Case study of the region of Liguria, Italy. WIT Trans. Ecol. Environ. 2018, 217, 523-534.

63. Hall, C.M. Constructing sustainable tourism development: The 2030 agenda and the managerial ecology of sustainable tourism. J. Sustain. Tour. 2019, 27, 1044-1060. [CrossRef]

64. Sharpley, R. Tourism, sustainable development and the theoretical divide: 20 years on. J. Sustain. Tour. 2020, 28, 1932-1946. [CrossRef]

65. Arnegger, J.; Woltering, M.; Job, H. Toward a product-based typology for nature-based tourism: A conceptual framework. J. Sustain. Tour. 2010, 18, 915-928. [CrossRef]

66. Pomering, A.; Noble, G.; Johnson, L.W. Conceptualising a contemporary marketing mix for sustainable tourism. J. Sustain. Tour 2011, 19, 953-969. [CrossRef]

67. Michailidou, A.V.; Vlachokostas, C.; Moussiopoulos, N.; Maleka, D. Life Cycle Thinking used for assessing the environmental impacts of tourism activity for a Greek tourism destination. J. Clean. Prod. 2016, 111, 499-510. [CrossRef]

68. Wong, P.P. Environmental impacts of tourism. In A Companion to Tourism; Wiley-Blackwell: Hoboken, NJ, USA, 2004; pp. 450-461 [CrossRef]

69. Azapagic, A.; Clift, R. The application of life cycle assessment to process optimisation. Comput. Chem. Eng. 1999, 23, 1509-1526. [CrossRef]

70. Estol, J.; Font, X. European tourism policy: Its evolution and structure. Tour. Manag. 2016, 52, 230-241. [CrossRef]

71. Finnveden, G.; Hauschild, M.Z.; Ekvall, T.; Guinée, J.; Heijungs, R.; Hellweg, S.; Koehler, A.; Pennington, D.; Suh, S. Recent developments in life cycle assessment. J. Environ. Manag. 2009, 91, 1-21. [CrossRef]

72. Heiskanen, E. The institutional logic of life cycle thinking. J. Clean. Prod. 2002, 10, 427-437. [CrossRef]

73. Hunkeler, D.; Rebitzer, G. The future of life cycle assessment. Int. J. Life Cycle Assess. 2005, 10, 305-308. [CrossRef]

74. Raggi, A.; Petti, L.; De Camillis, C.; Bordin, A.; Boatto, T. LCA dei prodotti turistici: Stato dell'arte e prospettive. In Proceedings of the 2nd Workshop Italian LCA Network 'Sviluppi dell'LCA in Italia: Percorsi a Confronto', Pescara, Italy, 18 March 2008; pp. 63-76.

75. Graedel, T.E. Life-cycle assessment in the service industries. J. Ind. Ecol. 1997, 1, 57-70. [CrossRef]

76. Tontodonati, S. Requisiti Specifici di Prodotto dei Servizi Alberghieri. Banchelor's Thesis, prof L Petti (supervisor), Università degli Studi “G. d'Annunzio", Pescara, Italy, 2002. 
77. Rosenblum, J.; Horvath, A.; Hendrickson, C. Environmental Implications of Service Industries. Environ. Sci. Technol. 2000, 34, 4669-4676. [CrossRef]

78. Hauschild, M.Z.; Rosenbaum, R.K.; Olsen, S.I. Life Cycle Assessment; Springer International Publishing: New York, NY, USA, 2018; Volume 2018. [CrossRef]

79. Finnveden, G.; Moberg, A. Environmental systems analysis tools-An overview. J. Clean. Prod. 2005, 13, 1165-1173. [CrossRef]

80. Becken, S.; Simmons, D.G.; Frampton, C. Energy use associated with different travel choices. Tour. Manag. 2003, 24, 267-277. [CrossRef]

81. Dolnicar, S. Identifying tourists with smaller environmental footprints. J. Sustain. Tour. 2010, 18, 717-734. [CrossRef]

82. Hunter, C.; Shaw, J. The ecological footprint as a key indicator of sustainable tourism. Tour. Manag. 2007, 28, 46-57. [CrossRef]

83. Kounina, A.; Margni, M.; Bayart, J.B.; Boulay, A.M.; Berger, M.; Bulle, C.; Frischknecht, R.; Koehler, A.; Canals, L.M.i.; Motoshita, M.; et al. Review of methods addressing freshwater use in life cycle inventory and impact assessment. Int. J. Life Cycle Assess. 2013, 18, 707-721. [CrossRef]

84. Ioannides, D.; Debbage, K.G. (Eds.) The Economic Geography of the Tourist Industry: A Supply-Side Analysis; Psychology Press: Hoove, UK, 1998.

85. Middleton, U. Tourist product. In Tourism Marketing and Management Handbook; Witt, S.F., Moutinho, L., Eds.; Prentice Hall: London, UK, 1989; pp. 572-576.

86. Smith, S.L. The tourism product. Ann. Tour. Res. 1994, 21, 582-595. [CrossRef]

87. Yin, R.K.; Hollweck, T.; Yin, R.K. Case Study Research Design and Methods; Sage: Washington, DC, USA, 2014.

88. Andereck, K.; Jurowski, C. Tourism and quality of life. In Quality Tourism Experiences; Routledge: London, UK, 2006 ; pp. 153-171.

89. Andersson, T.D. The tourist in the experience economy. Scand. J. Hosp. Tour. 2007, 7, 46-58. [CrossRef]

90. Vanhove, N. The Economics of Tourism Destinations; Routledge: London, UK, 2011.

91. De Camillis, C.; Raggi, A.; Petti, L. LCA: A key-tool for sustainable tourism. In Proceedings of the 8th International Conference on EcoBalamnce, Tokyo, Japan, 10-12 December 2008; Volume 1012, pp. 485-488.

92. De Camillis, C.; Peeters, P.M.; Petti, L.; Raggi, A. Tourism life cycle assessment (LCA): Proposal of a new methodological framework for sustainable consumption and production. In Visions for Global Tourism Industry-Creating and Sustaining Competitive Strategies; 2012; pp. 247-268. Available online: https:/ /www.intechopen.com/books/1852 (accessed on 20 December 2021).

93. Filimonau, V.; Dickinson, J.E.; Robbins, D.; Reddy, M.V. A critical review of methods for tourism climate change appraisal: Life cycle assessment as a new approach. J. Sustain. Tour. 2011, 19, 301-324. [CrossRef]

94. Scheepens, A.E.; Vogtländer, J.G.; Brezet, J.C. Two life cycle assessment (LCA) based methods to analyse and design complex (regional) circular economy systems. Case: Making water tourism more sustainable. J. Clean. Prod. 2016, 114, 257-268. [CrossRef]

95. Filimonau, V. Life Cycle Assessment (LCA) and Life Cycle Analysis in Tourism; Springer: Berlin/Heidelberg, Germany, 2016.

96. Gossling, S.; Peeters, P. Assessing tourism's global environmental impact 1900-2050. J. Sustain. Tour. 2015, 23, 639-659. [CrossRef]

97. Cupul-Magaña, A.L.; Rodríguez-Troncoso, A.P. Tourist carrying capacity at Islas Marietas National Park: An essential tool to protect the coral community. Appl. Geogr. 2017, 88, 15-23. [CrossRef]

98. Salerno, F.; Viviano, G.; Manfredi, E.C.; Caroli, P.; Thakuri, S.; Tartari, G. Multiple Carrying Capacities from a managementoriented perspective to operationalize sustainable tourism in protected areas. J. Environ. Manag. 2013, 128, 116-125. [CrossRef]

99. Milošević, S.; Perić, D.; Škrbić, I. How do residents assess the social impact of tourism? Menadz. Hotel. Turiz. 2021, 9, 103-119. [CrossRef]

100. McCombes, L.; Vanclay, F.; Evers, Y. Putting social impact assessment to the test as a method for implementing responsible tourism practice. Environ. Impact Assess. Rev. 2015, 55, 156-168. [CrossRef]

101. Fredline, L.; Deery, M.; Jago, L. Development of a Scale to Assess the Social Impacts of Tourism within Communities; CRC for Sustainable Tourism Pty Limited: Queensland, Australia, 2006.

102. Kim, W.; Jun, H.M.; Walker, M.; Drane, D. Evaluating the perceived social impacts of hosting large-scale sport tourism events: Scale development and validation. Tour. Manag. 2015, 48, 21-32. [CrossRef]

103. Pratt, S. The economic impact of tourism in SIDS. Ann. Tour. Res. 2015, 52, 148-160. [CrossRef]

104. Mazumder, M.N.H.; Al-Mamun, A.; Al-Amin, A.Q.; Mohiuddin, M. Economic Impact of Tourism-A Review of Literatures on Methodologies and Their Uses: 1969-2011. In Visions for Global Tourism Industry-Creating and Sustaining Competitive Strategies; 2012; pp. 269-294. Available online: https://www.intechopen.com/books/1852 (accessed on 20 December 2021).

105. Frechtling, D. The Economic Impact of Tourism: Overview and Examples of Macroeconomic Analysis. UNWTO Statistics and TSA Issues Paper Series. 2013. Available online: https://www.e-unwto.org/doi/pdf/10.18111/9789284415625 (accessed on 20 December 2021).

106. KrizaJ, D.; Sasidharan, V.; Franco, M.J.B. Illuminating Opportunities for Smart Tourism Innovation That Foster Sustainable Tourist Well-Being Using Q Methodology. Sustainability 2021, 13, 7929.

107. Roman, M.; Roman, M.; Prus, P.; Szczepanek, M. Tourism Competitiveness of Rural Areas: Evidence from a Region in Poland. Sustainability 2020, 10, 569. [CrossRef]

108. Gelbman, A. Tourist Experience and Innovative Hospitality Management in Different Cities. Sustainability 2021, 13, 6578. [CrossRef]

109. Borelli, S.; Minestrini, S.; Guarrera, L. Responsible Tourism in the Mediterranean; Principles and Codes of Conduct, World Wide Fund for Nature: Rome, Italy, 2000; pp. 1-17.

110. Candia, S.; Pirlone, F.; Spadaro, I. Tourism and Rural Landscape: Sustainable Development and Territorial Enhancement. In International Conference on Innovation in Urban and Regional Planning; Springer: Cham, Switzerland, 2021; pp. 531-539. 